\title{
MACHADO DE ASSIS E A HISTÓRIA: O PROCESSO ELEITORAL NAS CRÔNICAS DE "A SEMANA"
}

\section{BENITO PETRAGLIA}

Universidade Federal Fluminense

Niterói, Rio de Janeiro, Brasil

Resumo: Este artigo procura examinar o processo eleitoral no Império e sobretudo na Primeira República, através das crônicas de "A Semana" de Machado de Assis. Tenta estabelecer um confronto, especialmente no que se refere às fraudes eleitorais, entre as observações do cronista e as análises dos cientistas políticos.

Palavras-chave: eleições; crônica; Machado de Assis

\section{MACHADO DE ASSIS AND HISTORY: THE ELECTORAL PROCESS IN THE "A SEMANA" CHRONICLES}

Abstract: The aim of this article is to examine the electoral process in the Empire and mainly in the First Republic, through the chronicles written by Machado de Assis entitled "A Semana." It tries to establish a confrontation, especially with regard to electoral fraud, between the chronicler's observations and the analyses of political scientists.

Keywords: elections; cronicle; Machado de Assis 
Q uerem conhecer o processo eleitoral no Império e sobretudo na República Velha ou Primeira República? Dizendo a mesma coisa de outro modo: querem conhecer a história das fraudes desse período? Poderia dar-lhes, e darei, Rodolpho Telarolli, Sérgio Buarque de Holanda, Jairo Nicolau, Renato Lessa, José Murilo de Carvalho, Sidney Chalhoub, Victor Nunes Leal, eméritos conhecedores da matéria. Mas eles serão coadjuvantes. Dou-lhes o ator principal - Machado de Assis. Ele é que conduzirá essa história.

Que tal a combinação? A prosa incomparável do nosso maior escritor referendada pelas análises de abalizados especialistas.

Antes de entrar propriamente no assunto, fazem-se necessárias duas considerações preliminares. A primeira diz respeito à relação entre Machado de Assis e a história. Segundo Pedro Meira Monteiro, parece haver presentemente uma disputa em torno da figura de Machado. Para ele, "a fortuna crítica de Machado de Assis vem sendo pautada pela pergunta sobre a maior ou menor atenção que se deveria prestar à história para a compreensão do texto". ${ }^{1}$ Parte da fortuna crítica "apaga a história do horizonte de compreensão do texto "e outra parte "sequestra Machado de Assis, levando-o para a casa dos historiadores para chamá-lo de irmão". ${ }^{2}$

A despeito disso, afigura-se como matéria vencida a noção de que Machado de Assis era um escritor alheio aos acontecimentos do seu tempo. Espero que os próprios exemplos apresentados neste artigo se encarreguem dessa comprovação.

E a relação dele com a história? Machado faz várias menções a ela, tanto em ficção quanto em crônica. Em Memórias póstumas de Brás Cubas, o defunto autor nos faz entender que a história não produz relatos fidedignos - "a natureza é uma grande caprichosa e a história uma eterna loureira"; "a volúvel história que dá para tudo". ${ }^{3}$ Em Esaú e Jacó, permanece o sentimento de desconfiança, pois "um amanuense basta para trocar as mãos à História". 4

Como cronista ele também se refere à história, procurando, quase sempre, apontar diferenças em relação à crônica. Em 12 de junho de 1892, escreve:"Como simples crônica, posso achar explicações fáceis e naturais; mas

\footnotetext{
${ }^{1}$ MONTEIRO, O outono da escrita, p. 228.

2 Ibidem.

${ }^{3}$ ASSIS, Memórias póstumas de Brás Cubas, p. 103.

${ }^{4}$ ASSIS, Esaú e Jacó, p. 274.
} 
a história tem outra profundeza, não se contenta de coisas próximas e simples". ${ }^{5}$ Assim também na coluna de "A Semana" de 18 de novembro de 1894 :

[...] Um mestre de prosa, autor de narrativas lindas, curtas e duradouras, confessou um dia que o que mais apreciava na história eram as anedotas. Não discuto a confissão; digo só que, aplicada a este ofício de cronista, é mais que verdadeira. Não é para aqui que se fizeram as generalizações, nem os grandes fatos públicos. Esta é, no banquete dos acontecimentos, a mesa dos meninos.

Nem é preciso que o termo de comparação esteja presente. Ele pode estar subentendido, implícito, como na coluna de 28 de agosto de 1892: "Mas a História é pessoa entrada em anos, gorda, pachorrenta, meditativa, tarda em recolher documentos, mais tarda ainda em os ler e decifrar".

Essa percepção da história como ciência corresponde certamente à visão de mundo cética do autor de Dom Casmurro. Seu pensamento não se coadunava com a ideia de progresso. Uma feiticeira e um facultativo detêm a mesma prerrogativa de reivindicarem a cura de doenças.

A segunda consideração consiste em definir que parte da obra do escritor é mais apropriada para abordar o tema deste artigo. Creio que sejam justamente as crônicas das quais retirei alguns fragmentos. Duas razões sustentam a escolha. A primeira relaciona-se ao próprio gênero. $\mathrm{Na}$ crônica predomina a realidade factual, e a opinião do autor se mostra de maneira mais evidente. É certo que Machado, mesmo nelas, não cede à sua incoercível capacidade de fabular. Ainda que ele procure se esconder, a aderência ao acontecimento, congenial ao gênero, permite extrair o ponto de vista do cronista.

A segunda razão, talvez a mais importante, diz respeito às colunas escritas na Gazeta de Notícias, entre 1892 e 1897, sob o título "A Semana". O período abarcado por elas parece feito sob encomenda para tratar do processo eleitoral no Império e sobretudo na Primeira República. Ao mesmo tempo que se viviam os momentos instáveis do pós-golpe republicano, os "anos entrópicos", na expressão de Renato Lessa, a monarquia estava perto o suficiente para que Machado não a esquecesse, e, de vez em quando, tivesse

\footnotetext{
${ }^{5}$ ASSIS, A Semana, p. 72. A partir de agora, menciono apenas o dia, mês e ano das crônicas. Indicação suficiente para encontrá-las no IV volume da edição da Aguilar de 2008 da Obra completa de Machado de Assis; nos volumes 26, 27 e 28 das edições Jackson e no livro de Gledson para as crônicas de 1892 e 1893, como está nesta nota.
} 
"uma visão do passado, uma daquelas visões chamadas imperiais", como escreve na crônica de 18 de novembro de 1894.

Já na coluna inaugural de 24 de abril de 1892, a matéria é focalizada. Trata-se do pleito do dia 20 para preencher uma vaga no Senado, com a renúncia do general João Severiano da Fonseca. Foi eleito Aristides Lobo, que era deputado pelo Distrito Federal. Lembremos que o republicano Aristides Lobo se tornou conhecido por afirmar que o povo estivera ausente da proclamação do novo regime: "O povo assistiu àquilo bestializado, atônito, surpreso, sem conhecer o que significava. Muitos acreditavam sinceramente estar vendo uma parada". ${ }^{6} \mathrm{O}$ testemunho ficcional de Machado vai no mesmo sentido. Em Esaú e Jacó, no capítulo intitulado "Manhã de 15", o personagem Aires sai de casa para espairecer, e eis com o que se depara: "Quando Aires saiu do Passeio Público, suspeitava alguma cousa, e seguiu até o largo da Carioca. Poucas palavras e sumidas, gente parada, caras espantadas, vultos que arrepiavam caminho, mas nenhuma notícia clara nem completa". ${ }^{7}$

Pois nessa crônica ele registra - pretextando desconhecer a razão por não entender de política - a ausência do eleitor:

[...] não entendendo eu de política, ignoro se a ausência de tão grande parte do eleitorado na eleição do dia 20 quer dizer descrença, como afirmam uns, ou abstenção como outros juram. A descrença é fenômeno alheio à vontade do eleitor; a abstenção é propósito.

Gostaria de sublinhar dois pontos dessa passagem. O primeiro refere-se à alegação de não entender de política, que é insistentemente repetida: "Não entendo de política, limito-me a ouvir as considerações alheias" (25 de fevereiro de 1894); "política, matéria estranha às minhas cogitações" (6 de janeiro de 1895); "Não há quem não conheça a minha desafeição à política, e, por dedução, a profunda ignorância que tenho desta arte ou ciência" (7 de abril de 1895); "Nada entendendo de política nem de finanças" (8 de dezembro de 1895); "Não estranheis ver-me assim metido em política, matéria alheia à minha esfera de ação." (7 de junho de 1896). No entanto, a temática dominante nas crônicas é majoritariamente de cunho político, sendo a questão eleitoral apenas uma seção dela. Tais alegações, a meu ver, eram o artifício que ele empregava para eximir-se de polêmicas num momento de ânimos exaltados.

${ }^{6}$ CARONE, A primeira república, p. 377.

${ }^{7}$ ASSIS, Esaú e Jacó, p. 180. 
Já a distinção entre descrença e abstenção - eis o segundo ponto - é passível de ser aventada. Afirmar que a descrença "é fenômeno alheio à vontade do eleitor" significaria dizer que haveria razões de ordem mais geral, as quais justificariam sua ausência, ao passo que tomar a abstenção como propósito implicaria uma decisão individual.

$\mathrm{Na}$ crônica de 7 de agosto de 1892, volta ao assunto. Trata-se agora da eleição para uma cadeira na Câmara de Deputados pelo Distrito Federal, que vagara com a ida de Aristides Lobo para o Senado. E, de novo, o "eleitorado ficou em casa". "Uns querem ver nisto indiferença pública, outros descrença, outros abstenção. No que todos estão de acordo, é que é um mal, e grande mal."

Mas dessa vez a descrença ganha contornos, sugere-se o motivo:

[...] Conheço um homem que despendeu outrora vinte anos de existência em falsificar atas, trocar cédulas, quebrar urnas, e que me dizia ontem, quase com lágrimas, que o povo já não crê em eleições. "Ele sabe" acrescentou fazendo um gesto conspícuo - "que o seu voto não será contado."

Também para a abstenção sugere-se um motivo. É que não havendo "gozo pessoal", o eleitor deixa-se vencer pela inércia:

Façam-me o favor de dizer que pitoresco e que espécie de gozo pessoal há em uma eleição? Sair de casa sem almoço (em domingo, note-se!), sem leitura de jornais, sem sofá ou rede, sem chambre, sem um ou dois pequerruchos, para ir votar em alguém que o represente no Congresso, não é o que vulgarmente se chama caceteação?

Não importa saber, no que toca ao que se diz sobre a descrença, se o que se conta é uma ironia ou uma invenção do cronista. O que importa é sua inequívoca verossimilhança. Assis Brasil, na Constituinte de 1934, assim se exprimiu:

No regime que botamos abaixo com a Revolução [Revolução de 30], ninguém tinha certeza de que lhe fosse contado o voto... Uma vez contado o voto, ninguém tinha a segurança de que seu eleito havia de ser reconhecido através de uma apuração feita dentro desta Casa e por ordem, muitas vezes, superior. ${ }^{8}$

${ }^{8}$ ASSIS BRASIL. Apud LEAL, Coronelismo, enxada e voto, p. 215. 
Pode-se objetar que a crônica fala de alguém que há vinte anos vem cometendo fraudes, portanto, no tempo do Império; enquanto que o discurso de Assis Brasil se refere à Primeira República. Objeção igualmente sem tanta importância, pois a "mácula da corrupção, verberada sem exceção pelos estudiosos das nossas instituições, atravessa toda a história do Império e da Primeira República". ${ }^{9}$

Registre-se, por outro lado, que, nesse discurso, Assis Brasil indica que a fraude era cometida em cada etapa do processo eleitoral, como José Murilo de Carvalho evidencia de modo mais claro: "Havia fraude no alistamento dos eleitores, fraude na votação, fraude na apuração dos votos, fraude no reconhecimento dos eleitos". ${ }^{10}$

Nessa mesma coluna (7 de agosto de 1892), o cronista menciona os partidos como os organismos que poderiam ajudar o eleitor a sair de sua inércia. "Mas que fazer, se não há partidos?" Com efeito, a extinção dos partidos Conservador e Liberal, com o fim do Império, deixou um vácuo que passou a ser preenchido por seções oligárquicas dominadas por chefes estaduais (PRP, PRM, PRR). Somente em "julho de 1893, sob a liderança de Francisco Glicério, republicano histórico paulista, fundou-se o Partido Republicano Federal". ${ }^{11}$ Único partido de âmbito nacional, no entanto, ou por isso mesmo, tornou-se um partido disfuncional. Agregaram-se a ele pessoas de todos os credos políticos, até simpatizantes da Revolta da Armada.

Na crônica de 30 de outubro de 1892, Machado aborda a eleição para intendentes, a realizar-se nesse mesmo dia, um domingo. Os intendentes eram os antigos vereadores da Câmara Municipal, também chamada de Senado da Câmara do Rio de Janeiro dos tempos do Império, dissolvida pelo decreto 50A de 7 de dezembro de 1889, que "instituiu em seu lugar um Conselho de Intendência Municipal encarregado de administrar a capital". ${ }^{12}$

O Conselho de Intendência apresentou dois períodos:

O primeiro de 1889 a 1892 e o segundo de 1892 em diante. O marco que divide e caracteriza estes dois momentos é a promulgação da Lei Orgânica do DF [Distrito Federal] de 20.09.1892, que alterou significativamente o processo de representação. No primeiro período os

\footnotetext{
${ }^{9}$ LEAL, cit., p. 222.

10 CARVALHO, Os três povos da República, p. 105.

${ }^{11}$ LESSA, A invenção republicana, p. 75.

12 BASTOS, O conselho de intendência municipal, p. 7. Aproveito para agradecer a Ana Marta Rodrigues Bastos, autora desse importante trabalho, o empenho e a generosidade de me permitir ter acesso a ele.
} 
Intendentes eram nomeados pelo presidente da República e no segundo eram eleitos pela população alistável. ${ }^{13}$

Assim, a lei de 20 de setembro de 1892 atribui a gestão do Distrito Federal a um prefeito, designado pelo presidente da República, e a um Conselho Municipal formado por 27 intendentes eleitos.

Portanto, como afirma o cronista: "Trata-se não menos que de eleger o primeiro conselho municipal do Distrito Federal, que é ainda e será a capital verdadeira e histórica do Brasil".

Mas o que chama a atenção nessa crônica, como em outras que versam sobre a questão eleitoral, é encontrarmos um Machado de Assis diferente do que estamos habituados a ler. Ele é categórico, assertivo, um pregador a estimular a cidadania, o direito e o dever do voto. O próprio fato de afirmar que a indiferença, a descrença, a abstenção são "um mal, e grande mal " (7 de agosto de 1892), de certa maneira, o distancia da visão de mundo com que nos acostumou, em que tudo é relativo - "Mas que há neste mundo que se possa dizer verdadeiramente verdadeiro? Tudo é conjetural" (crônica de 3 de março de 1895) -, em que "o vício é muitas vezes o estrume da virtude". ${ }^{14}$

Vejamos então como se dá essa faceta de um Machado doutrinador. Nessa mesma crônica de 30 de outubro de 1892, por duas vezes, ele exorta o leitor a ir votar - no meio e no final dela: "Por hoje, leitor amigo, vai tranquilamente dar o teu voto. Vai, anda, vai escolher os intendentes que devem representar-nos e defender os interesses comuns da nossa cidade"; "Mas não me faças ir adiante, leitor amado. Adeus, vai votar. Escolhe a tua intendência e ficarás com o direito de gritar contra ela. Adeus".

Em 25 de fevereiro de 1894, a convocação é para eleger em $1^{\circ}$ de março, pelo voto direto do povo, o primeiro presidente da República. Como é sabido, Deodoro e Floriano foram eleitos presidente e vice pela Assembleia Constituinte, um dia depois da promulgação da Constituição de 24 de fevereiro de 1891. O cronista adota o mesmo tom exortativo dos exemplos anteriores:

[...] Trata-se de teu dia, povo soberano, rei sem coroa nem herdeiro, porque és continuamente rei, é o dia em que tens de escolher os teus ministros, a quem confias, não o princípio soberano, que esse fica sempre em ti, mas o exercício do teu poder. Vais dar o que, por outras palavras, se chama veredictum da opinião ou sentença das urnas.

\footnotetext{
${ }^{13}$ Idem, p. 1.

${ }^{14}$ ASSIS, Memórias póstumas de Brás Cubas, p. 214.
} 
Em 15 de julho de 1894, a eleição é para presidente do Estado: "Quando estas linhas aparecerem aos olhos dos leitores, é de crer que toda a população eleitoral do Rio de Janeiro caminhe para as urnas, a fim de eleger o presidente do Estado."

A crônica de 9 de dezembro de 1894 ocupa-se da renovação da Intendência:

[...] Aposto que o leitor não sabe que tem de eleger no último domingo deste mês os seus representantes municipais? Não sabe. Se soubesse, já andaria no trabalho da escolha do candidato, em reuniões públicas, ouvindo pacientemente a todos que viessem dizer-lhe o que pensam e o que podem fazer. Quando menos, estaria lendo as circulares dos candidatos, cujos nomes andariam já de boca em boca, desde dois e três meses, ou apresentados por si mesmos, ou indicados por diretórios.

Vê-se, por esses exemplos, a importância que Machado confere ao eleitor. Ele seria, por assim dizer, o agente que deflagraria e garantiria a operação de votar. Embora reconhecendo que a fraude e a violência fossem obstáculos ponderáveis, não deveriam desanimá-lo ou intimidá-lo. Talvez seja por isso que fustigue tanto o eleitor, como na crônica de 15 de outubro de 1893 : "O eleitor é, em grande parte, distraído, indolente e um pouco ignorante". Sim, distraído, porque um acontecimento extraordinário, um "grande crime", pode dispersar sua atenção:

Agora, o mal que resulta deste grande crime, é não sabermos se ficará bastante curiosidade para acudir à eleição dos intendentes. Talvez não. Eleitor não é gato de sete fôlegos. Deixa-se ficar almoçando; os intendentes vão ser eleitos a cinquenta votos. Poucas semanas depois, trinta mil eleitores sairão de casa murmurando que a intendência não presta para nada. (Crônica de 25 de setembro de 1892)

Mas a sentença definitiva está na crônica de 15 de julho de 1894, já citada, que fala da eleição de presidente do Estado:

Ninguém ignora que nas batalhas como a de hoje costuma roncar o pau. Esta arma, força é dizê-lo, anda um tanto desusada, mas é tão útil, tão sugestiva, que dificilmente será abolida neste final de século e nos primeiros anos do outro. Não é épica nem mística, está longe de competir com a lança de Aquiles [...]. Mas a arma é como o estilo, a melhor é que se 
adapta ao assunto. Que viria fazer a lança de Aquiles entre um capanga sem letras e um eleitor sem convicção? Menos, muito menos que o vulgar cacete.

Aqui eu poderia ilustrar esse comentário com a observação de José Murilo de Carvalho, que confirmaria o seu acerto: "Na capital da República, a abstenção não era produzida por oligarquias. Era devida ao puro medo. As eleições eram batalhas comandadas por capangas armados de facas e navalhas. Quem tinha juízo ficava em casa". ${ }^{15}$

Poderia, mas teria necessariamente que consignar a diferença entre a constatação do analista e o desejo do escritor, ou, em termos mais simples, entre "ficar em casa" e "sair de casa". Pois logo a seguir o cronista aplica o que chamei a "sentença definitiva" ao "grande mal":

O grande mal das eleições não é o pau, nem talvez a pena, é a abstenção, que dá resultados muita vez ridículos. Urge combatê-la. Cumpre que os eleitores elejam, que se movam, que saiam de suas casas para correr às urnas, que se interessem, finalmente, pelo exercício do direito que a lei lhes deu, ou lhes reconheceu.

A despeito disso, ele não deixou em suas crônicas de falar em "eleições violentas e corrutas, a bico de pena, a bacamarte, a faca e a pau" ( 24 de março de 1895). Quase todo o repertório de fraudes eleitorais está relacionado nelas. Poderíamos cotejá-lo com a lista apresentada por Jairo Nicolau, cientista político especializado em sistemas eleitorais.

Façamos uma comparação entre os tipos de fraudes anotados por Machado de Assis e os apontados pelo cientista político. ${ }^{16}$ Como disse, eram práticas que vinham do Império e continuaram na Primeira República:

- Uso de ameaças e violências por intermédio de capangas: "podem os capangas tolher a reunião das mesas eleitorais" (8 de dezembro de 1895);

- Adulteração das atas eleitorais (eleições a bico de pena): "A pena, 'o bico de pena', segundo a expressão clássica, traz vantagens relativas, não tira sangue de ninguém; não faz vítimas, faz atas, faz eleitos" (15 de julho de 1894);

- Voto de eleitores fantasmas ("o fósforo"): "O meu título de eleitor não é dos que ficaram devolutos para que um cidadão anônimo pegasse deles e os oferecesse a outros" (27 de dezembro de 1896).

${ }^{15}$ CARVALHO, cit., p. 106.

16 NICOLAU, Eleições no Brasil, p. 43. 
A propósito desta última transcrição, vale a pena continuá-la para de novo ilustrar uma espécie de lição de cidadania que ele parece querer incutir no leitor:

[...] Um dos eleitores defraudados confessou que não vota há muitos anos. Pois se não vota, como é que se admira de que lhe tirem o título? [...] Um eleitor que é? Um simples homem, não diverso de outro homem que não seja eleitor [...]. Que é que os faz diferentes? Esse pedaço de papel que leva em si um pedaço de soberania. O homem pode ser banqueiro, agricultor, operário, comerciante, advogado, médico, pode ser tudo; eleitoralmente é como se não existisse: sem título, não é eleitor.

Um dos assuntos da crônica de 7 de abril de 1895 é a apuração dos votos na Bahia. Os dois partidos do Estado não se entendem. Tentam uma conciliação. Mas o que espanta o escritor são os termos de uma das tentativas:

Uma das tentativas esteve quase a produzir fruto; foi inútil porque um dos partidos cedia o terço no Senado e na Câmara dos deputados, solução que o outro partido recusou, exigindo dezoito deputados, maioria e presidência do Senado. Ecco il problema.

Esse ceder um terço, esse exigir dezoito deputados, no ato da apuração, juro por todos os santos do céu e por todas as santas da terra, não me entra na cabeça. [grifos do autor]

Também nos espantaríamos, se o estudo clássico de Victor Nunes Leal não nos tivesse apresentado ao "coronelismo": "A explicação do fenômeno está no governismo dos chefes locais [...] e na sujeição do eleitorado do interior, especialmente do rural, a esses mesmos chefes, como consequência direta da nossa estrutura agrária, que deixa o trabalhador do campo ignorante e desamparado". ${ }^{17}$

Machado refere-se ainda a "urnas [...] pejadas" (30 de outubro de 1892), por "alguma lei biológica, as urnas concebem" (7 de abril de 1895), isto é, urnas nas quais foram introduzidas cédulas antes da votação.

Mas afirmei que ele menciona "quase " todo o repertório de fraudes. De fato, salvo engano, uma única modalidade está ausente. Ficou conhecida nos meios políticos como "degola". Ocorria na etapa final da eleição. Era praticada nas câmaras legislativas, através da chamada Comissão de Verificação de Poderes, que procurava excluir os que não pertencessem à facção governista.

${ }^{17}$ LEAL, cit., p. 228. 
A ausência talvez decorra daí, pois era realizada num momento e numa situação pouco visível para a opinião pública, como explica Telarolli:

O 'bico-de-pena' e o voto de 'defuntos' são as formas mais referidas, pela frequência com que foram praticadas, sob o testemunho popular. A 'degola', por exemplo, se dava distante dos pontos de atuação do eleitor, à qual era ele totalmente alheio, pois sua prática ocorria nos recintos das casas legislativas. ${ }^{18}$

Em suma, admitia-se todo tipo de fraude, imoral era não ser eleito: "Casos há em que nem vão [eleitores] às urnas; é o que elegantemente se chama bico de pena. Uns dizem que este processo é imoral; outros que imoral é ficar de fora" (crônica de 6 de dezembro de 1896). Esta passagem é quase a reprodução do que está em Leal, que cita Calógeras: "Segundo Calógeras, era 'considerada por todos, indistintamente, única falta moral para o partido no poder, o perder a eleição. E, para tal fim, qualquer processo, por mais fraudulento que fosse, era admitido'". ${ }^{19}$

E ele oferece remédios para a cura das mazelas eleitorais? E se oferece, quais seriam? Acaso, a única opinião sincera, e desalentada, que apresenta a esse respeito se encontra na coluna de 8 de dezembro de 1895, em que, mais uma vez, afirma não entender de política, agora, como justificativa:

Mas, que remédio dou então para fazer todas as eleições puras? Nenhum; não entendo de política. Sou um homem que, por ler jornais e haver ido em criança às galerias das câmaras, tem visto muita reforma, muito esforço sincero para alcançar a verdade eleitoral, evitando a fraude e a violência, mas por não saber de política, ficou sem conhecer as causas do malogro de tantas tentativas.

Única opinião sincera, porque, em verdade, em outras crônicas, ele discute e propõe soluções, só que aparentemente numa chave irônica. A ressalva se faz necessária, pois os machadianos conhecem seus meneios argumentativos, suas artimanhas de encobrir e descobrir, e a dificuldade que isso importa em extrair a "opinião sincera". De todo modo, comecemos pela "solução" apresentada no Império e lembrada por Machado na crônica de 17 de maio de 1896:

18 TELAROLLI, Eleições e fraudes eleitorais na República Velha, p. 78.

${ }^{19}$ LEAL, cit., p. 325. 
[...] Um dia, apareceu a Lei Saraiva, destinada a fazer eleições sinceras e sossegadas. Estas passaram a ser de um só grau. Oh! ainda agora me não esqueceram os discursos que ouvi, nem os artigos que li por esses tempos atrás, pedindo a eleição direta! [...] Eu, pobre rapaz sem experiência, ficava embasbacado quando ouvia dizer que todo o mal das eleições estava no método; mas, não tendo outra escola, acreditava que sim, e esperava a lei.

[...] A convicção é que se tinha achado a panaceia universal.

"Houve sobretudo, a busca de uma espécie de panaceia, capaz de erradicar o universo dos vícios eleitorais. A ideia à qual se atribuíram vários efeitos curativos foi a de eleições diretas." ${ }^{20}$

"Achava-se que tal reforma, ao estabelecer eleições diretas, seria panaceia para todos os males do país."21

Renato Lessa e Sidney Chalhoub teriam lido Machado de Assis? Responder sim ou não à pergunta não é o relevante. A questão que quero enfatizar é que se formou quase um consenso entre os historiadores de que o problema não estava exatamente no processo eleitoral, mas era devido a uma espécie de parlamentarismo à brasileira. Lembremos que a Lei Saraiva foi elaborada com o propósito de evitar as câmaras unânimes, de proporcionar representação às minorias. Pela Constituição de 1824, a votação era indireta ou em dois graus: os cidadãos "votantes" escolhiam os "eleitores" (primeiro grau) e estes, por sua vez, elegiam os parlamentares (segundo grau). Havia, porém, uma restrição: para ser votante era preciso comprovar a obtenção de uma renda mínima anual de 100 mil réis e para ser eleitor de 200 mil réis. Com a Lei Saraiva (9 de janeiro de 1881), o sufrágio foi reduzido a um só grau, mas ainda exigindo uma renda anual mínima de 200 mil réis.

Como disse, entretanto, o problema não estava na reforma das leis eleitorais, e sim na existência do que chamei "parlamentarismo à brasileira", manipulado pelo Poder Moderador, ou seja, D. Pedro II: "Apesar das sucessivas reformas, as eleições no Império sempre deixaram muito a desejar. Para julgá-las em conjunto, basta observar a feição peculiar do nosso parlamentarismo, com a rotatividade dos partidos dependendo predominantemente, quando não exclusivamente, do critério pessoal do monarca". ${ }^{22}$ "Tudo parece indicar a presença de um singular sistema de eleitor

\footnotetext{
${ }^{20}$ LESSA, cit., p. 28.

${ }^{21}$ CHALHOUB, Machado de Assis, historiador, p. 283.

${ }^{22}$ LEAL, cit., p. 223.
} 
único, capaz de encarnar a vontade nacional." ${ }^{23}$ "Como as eleições só produziam [...] resultados que pudessem interessar aos elementos que Sua Majestade houvesse por bem conservar [...], todos os recursos possíveis para a estabilidade ou a substituição dos grupos dirigentes ficavam enfeixados nas mãos de um homem só. [...] A vontade do povo ficava reduzida [...] à vontade do Imperador." 24

Apesar de sua velada preferência pelo parlamentarismo, o próprio Machado não deixa de notar a natureza do nosso "singular sistema", ao compará-lo com o das Ilhas Britânicas:

Ontem, sábado, fez-se a eleição de um senador pelo Distrito Federal. Votei; estou bem com a lei e a minha consciência. [...]

A coincidência da eleição aqui com a da Câmara dos comuns de Inglaterra fez-me naturalmente refletir sobre os processos de ambos os países. Não aludo aos trinta mil discursos que se fazem nas ilhas britânicas diante de eleitores que desejam ouvir o pensamento dos candidatos. Os candidatos aqui estariam prontos a dizer o que pensam; mas é incerto que as reuniões fossem concorridas. Demais, basta ler a última sessão da Câmara dissolvida para conhecer a diversidade dos costumes. Quando um dos ministros deu notícia de que o gabinete estava demitido e havia sido chamada a oposição ao governo, levantou-se o líder desta, e bradou contra o gabinete liberal, por não ter dissolvido a Câmara, impondo agora essa tarefa à oposição. Nós, quando tínhamos parlamentarismo, o ato da oposição seria diverso; dir-se-iam algumas palavras duras à coroa, outras mais duras aos ministros novos, e cada qual ia cuidar do seu ofício. (Crônica de 21 de julho de 1895).

Dirigiam-se "palavras duras à coroa", porque era o Poder Pessoal que decidia. Cumpria-se assim o famoso sorites formulado por Nabuco de Araújo: "O Poder Moderador pode chamar a quem quiser para organizar ministérios; esta pessoa faz a eleição porque há de fazê-la; esta eleição faz a maioria. Eis aí está o sistema representativo do nosso país"25. Diríamos, em termos mais simples, com Jairo Nicolau, que "enquanto na Inglaterra o governo era formado de baixo para cima, no Brasil ele era formado de cima para baixo". ${ }^{26}$

Compreende-se então que a reforma da legislação eleitoral não era solução para o problema. Além de não assegurar a representação das minorias,

\footnotetext{
${ }^{23}$ LESSA, cit., p. 45.

${ }^{24}$ HOLANDA, Do Império à República, p. 73.

${ }^{25}$ Apud NABUCO, Um estadista do Império, p. 766.

${ }^{26}$ NICOLAU, cit., p. 45.
} 
um dos objetivos com os quais fora criada ainda reduziu o "eleitorado brasileiro de 1.114 .066 para 145.296 votantes". ${ }^{27}$ À restrição do censo econômico somava-se a do censo literário. A partir dela, os novos eleitores precisavam saber ler e escrever. "A ilusão moralizadora cai por terra: na terceira eleição pós-Saraiva, o Brasil retoma seus trilhos."28 Ou seja, os trilhos da fraude, da violência e das câmaras majoritárias.

Recorde-se que a ficção machadiana, através do conto "A sereníssima república", publicado na Gazeta de Notícias em 8 de setembro de 1882 e depois na coletânea de Papéis avulsos (1882), também teve como escopo, ainda que de modo alusivo, a Lei Saraiva. Ele mesmo acrescenta uma nota que dá ensejo a essa interpretação: "Este escrito [...] é o único em que há um sentido restrito: - as nossas alternativas eleitorais". ${ }^{29}$

Já a crônica de 8 de dezembro de 1895 discute a proposta do deputado Nilo Peçanha, que apresentou "um projeto de lei destinado a impedir a fraude e as violências nas eleições [...]. Onde, à hora marcada, não houver funcionários, o eleitor vai a um tabelião e registra o seu voto". Não seria uma solução, seria simplesmente transferir o problema de lugar. Mas melhor é deixar o mestre falar, saborear suas palavras, seu engenho e arte:

Como tabelião, é que não sei se aprovaria a lei. O tabelião é um ente modesto, amigo da obscuridade, metido consigo, com os seus escreventes, com as suas escrituras, com o seu Manual. [...] Se algum, por ter parentes no partido teixeirista, mandar espancar pelos escreventes os eleitores dominguistas, cometerá realmente um crime, e incitará algum colega aparentado com o cabo dos dominguistas a restituir aos teixeiristas as pancadas distribuídas em nome daqueles. Deixemos os tabeliães onde eles devem ficar - nos romances de Balzac, nas comédias de Scribe e na rua do Rosário.

A partir de agora, menciono as crônicas nas quais os remédios indicados para a cura do mal contêm um concentrado teor de ironia. Na maioria delas, sugere-se transformar o processo eleitoral em sorteio, aposta, loteria:

- 7 de agosto de 1892: Se o "eleitor não vai à urna, a urna vai ao eleitor";

- 25 de fevereiro de 1894: "Quem [...] comparar a eleição e a loteria terá achado uma ideia, posto que óbvia, interessante";

${ }^{27}$ LESSA, cit., p. 24.

28 Idem, p. 31.

${ }^{29}$ ASSIS, Papéis avulsos, p. 253. A propósito, creio que Machado escreveu uma nova versão desse conto na crônica de 3 de janeiro de 1897. É o que se vai conferir no texto anexo, do qual retirei três ou quatro linhas para assegurar o caráter totalmente ficcional do relato. Intitulei-o "Trumpbal". 
- 15 de julho de 1894: "acho que a reforma eleitoral, para ser útil e fecunda, há de consistir em dar às eleições um aspecto acentuadamente esportivo. [...] A lei deve ordenar que os candidatos sejam objeto de apostas";

- 3 de fevereiro de 1895: "[...] talvez fosse melhor trocar o modo eleitoral, substituindo o voto pela sorte. A sorte é fácil e expedita; escrevem-se os nomes dos candidatos, metem-se as cédulas dentro de um chapéu, e o nome escrito na cédula que sair é o eleito";

- 24 de março de 1895:

Não amando o sangue, temendo as incertezas da fraude, e julgando as eleições necessárias, como achar um modo de as fazer sem nenhum desses riscos? [...] Suprimo as eleições. [...]

Sabeis muito bem o que eram os pelouros antigamente. Eram umas bolas de cera, onde se guardavam, escritos em papel, os nomes dos candidatos à vereação; abriam-se as bolas no fim do prazo da lei, e os nomes que saíam eram os escolhidos para a magistratura municipal. Pois este processo do Antigo Regime é o que me parece capaz de substituir o atual mecanismo [...].

Com tudo isso, vimos que, ao se estabelecer o confronto das ponderações "sérias" do cronista com as análises dos cientistas políticos, há uma notável coincidência, até de palavras, entre elas. Machado de Assis não era cientista político. Mas sua visão de mundo, seu distanciamento cético dos acontecimentos lhe permitiam emitir juízos imparciais, ainda que manifestando aqui e ali, dissimuladamente, suas preferências por sistemas e regimes de governo.

Por outro lado, é curioso notar-se, no que toca ao incitamento do leitor a votar e exercer seu direito soberano, uma certa mudança de estilo. Ele, como diz de si mesmo, cuja natureza é andar "no caminho direito, que é na planície", no entanto, tem "uns dias, umas horas", em que dá "para subir a montanha e doutrinar os homens" (crônica de 27 de janeiro de 1895).

Por fim, outra curiosidade, e esta infelizmente não poderá ser satisfeita, é saber o que ele nos teria a dizer sobre as eleições no momento presente. Parece que o processo eleitoral em si se aperfeiçoou. Contudo, avolumam-se as barganhas escusas que gravitam em torno dele, deturpando a autenticidade da representação popular. Uma comprovação, agora como antes, de que a questão de fundo não reside nos métodos ou regras eleitorais, mas em nossa estrutura social, marcada desde sempre por profunda desigualdade. 


\section{Referências}

ASSIS, Machado de. A Semana - crônicas (1892-1893). Edição, introdução e notas de John Gledson. São Paulo: Hucitec, 1996.

_. Esaú e Jacó. Rio de Janeiro: Civilização Brasileira; Brasília: INL, 1975.

. Memórias póstumas de Brás Cubas. Rio de Janeiro: Civilização Brasileira; Brasília: INL, 1975.

Obra completa de Machado de Assis: volume IV. São Paulo: Nova Aguilar, 2008

Papéis avulsos. São Paulo: Penguin-Companhia das Letras, 2011.

BASTOS, Ana Marta Rodrigues. O conselho de intendência municipal: autonomia e instabilidade (1889-1892). Rio de Janeiro: FCBR, 1984. Mimeografado.

CARONE, Edgar. A Primeira República (1889-1930): texto e contexto. 3. ed. São Paulo: Difel, 1976.

CARVALHO, José Murilo de. Os três povos da República. Revista USP, São Paulo, n. 59, set./nov. 2003, p. 96-115.

CHAlHOUB, Sidney. Machado de Assis; historiador. São Paulo: Companhia das Letras, 2003.

HOLANDA, Sérgio Buarque de. Do Império à República. 3. ed. São Paulo: Difel, 1983. LEAL, Victor Nunes. Coronelismo, enxada e voto: o município e o regime representativo no Brasil. 7. ed. São Paulo: Companhia das Letras, 2012.

LESSA, Renato. A invenção republicana: Campos Sales, as bases e a decadência da Primeira República brasileira. São Paulo: Vértice, Revista dos Tribunais; Rio de Janeiro: IUPERJ, 1988.

MONTEIRO, Pedro Meira. O outono da escrita. Novos Estudos Cebrap, São Paulo, v. 35 , n. 2, jul. 2016, p. 227-239.

NABUCO, Joaquim. Um estadista do Império. 5. ed. Rio de Janeiro: Topbooks, 1997. NICOLAU, Jairo Marconi. Eleições no Brasil: do Império aos dias atuais. Rio de Janeiro: Zahar, 2012.

TELAROLLI, Rodolpho. Eleições e fraudes eleitorais na República Velha. São Paulo: Brasiliense, 1982. 


\section{ANEXO \\ Trumpbal}

A importância da carta que se vai ler devia excluir qualquer outro cuidado esta semana; mas não se perde nada em retificar um lapso. Pequeno lapso: domingo passado escrevi "autor de Fleurs du Mal" onde devera escrever "autor de Blasphèmes", tudo porque uma estrofe de Baudelaire me cantava na memória para corrigir com ela o seu patrício Richepin. Vamos agora à carta. Recebi-a anteontem de um cidadão americano, o rev. M. Going, que aqui chegou em agosto do ano findo e partiu a 1 ou 2 de setembro para a ilha da Trindade. - "Suspeito uma cousa", disse-me ele. - "Que cousa?" - "Não posso dizer; se acertar, terei feito uma grande descoberta, a maior descoberta marítima do século; se não acertar, fica o segredo comigo." Podes imaginar agora, leitor, o assombro com que recebi a epístola que vais ler:

"Ilha da Trindade, 26 de dezembro de 1896.

"Caro senhor. - Esta carta vos será entregue pelo rev. James Maxwell, de Nebrasca. Veio ele comigo a esta ilha, sem saber o fim que me trouxe a ela. Pensava que o meu desejo era conhecer o valor do penhasco que os ingleses queriam tomar ao Brasil, segundo lhe disse em Royal Hotel, 3, rua Clapp, uma sexta-feira. O rev. Maxwell vos contará o assombro em que ficou e a minha desvairada alegria quando vimos o que ele não esperava ver, o que absolutamente ninguém pensou nem suspeitou nunca.

"Senhor, esta ilha não é deserta, como se afirma; esta ilha tem, do lado oriental, uma pequena cidade, com algumas vilas e aldeias próximas. Eu desconfiava disto, não por alguma razão científica ou confidência de navegante, mas por uma intuição fundada em tradição de família. Com efeito, é constante na minha família que um dos meus avós, aventureiro e atrevido, deixou um dia as costas da Inglaterra, entre 1648 e 1650, em um velho barco, com meia dúzia de tripulantes. Voltou dez anos depois, dizendo ter descoberto um povo civilizado, bom e pacífico, em certa ilha que descreveu. Não temos outro vestígio; mas, não sei por que razão - creio que por inspiração de Deus - desconfiei que a ilha era a da Trindade. E acertei; eis a ilha, eis o povo, eis a grande descoberta que vai fechar com chave de ouro o nosso século de maravilhas.

"As notícias atropelam-se-me debaixo da pena, de modo que não sei por onde continue. A primeira cousa que lhe digo já é que achei a prova da estada aqui de um Going, no século XVII. Dei com um retrato de Carlos I, meio 
apagado e conservado no museu da cidade. Disseram-me que fora deixado por um homem que residiu aqui há tempos infinitos. Ora, o meu avô citado era grande realista e por algum tempo bateu-se contra as tropas de Cromwell. Outra prova de que um inglês esteve aqui é a língua do povo, que é uma mistura de latim, inglês e um idioma que o rev. Maxwell afirma ser púnico. Efetivamente, este povo inculca descender de uma leva de cartagineses que saiu de Cartago antes da vitória completa dos romanos. Uma vez entrados aqui, juraram que nenhuma relação teriam mais com povo algum da terra, e assim se conservaram. Quando a população chegou a vinte e cinco mil almas, fizeram uma lei reguladora dos nascimentos, para que nunca esse número seja excedido; único modo, dizem, de se conservarem segregados da cobiça e da inveja do universo. Não é essa a menor esquisitice desta pequena nação; outras muitas tem, e todas serão contadas na obra que empreendi. Porquanto, meu caro senhor, é meu intuito não ir daqui sem haver descrito os costumes e as instituições do pequenino país que descobri, dizendo de suas origens, raça, língua o mais que puder coligir e apurar. Talvez lhe traga dano. Não é fora de propósito crer que a Inglaterra, sabendo que aqui esteve um inglês, há dous séculos, reclame a posse da ilha; mas, em tal caso, sendo Going meu parente, reivindicarei eu a posse e vencerei por um direito anterior. De fato, todo ente gerado, antes de vir à luz, antes de ser cidadão, é filho de sua mãe, e até certo ponto é avô da geração futura que virtualmente traz em si. Vou escrever neste sentido a um legista de Washington.

"Falei de esquisitices. Aqui está uma, que prova ao mesmo tempo a capacidade política deste povo e a grande observação dos seus legisladores. Refiro-me ao processo eleitoral. Assisti a uma eleição que aqui se fez em fins de novembro. Como em toda parte, este povo andou em busca da verdade eleitoral. Reformou muito e sempre; esbarrava-se, porém, diante de vícios e paixões, que as leis não podem eliminar. Vários processos foram experimentados, todos deixados ao cabo de alguns anos. É curioso que alguns deles coincidissem com os nossos de um e de outro mundo. Os males não eram gerais, mas eram grandes. Havia eleições boas e pacíficas, mas a violência, a corrução e a fraude inutilizavam em algumas partes as leis e os esforços leais dos governos. Votos vendidos, votos inventados, votos destruídos, era difícil alcançar que todas as eleições fossem puras e seguras. Para a violência havia aqui uma classe de homens, felizmente extinta, a que chamam pela língua do país, kapangas ou kapengas. Eram esbirros particulares, assalariados para amedrontar os eleitores e, quando fosse preciso, quebrar as urnas e as cabeças. Às vezes quebravam só as cabeças e metiam nas urnas maços de cédulas. Estas 
cédulas eram depois apuradas com as outras, pela razão especiosa de que mais valia atribuir a um candidato algum pequeno saldo de votos que tirar-lhe os que deveras lhe foram dados pela vontade soberana do país. A corrução era menor que a fraude; mas a fraude tinha todas as formas. Enfim, muitos eleitores, tomados de susto ou de descrença, não acudiam às urnas.

"Vai então, há cinquenta anos (os anos aqui são lunares) apareceu um homem de Estado, autor da lei que ainda hoje vigora no país. Não podeis, caro senhor, conceber nada mais estranho nem também mais adequado que essa lei: é uma obra-prima de legislação experimental. Esse homem de Estado, por nome Trumpbal, achou dificuldades em começo, porque a reforma proposta por ele mudava justamente o princípio do governo. Não o fez, porém, pelo vão gosto de trocar as cousas. Trumpbal observara que este povo confia menos em si que nos seus deuses; assim, em vez de colocar o direito de escolha na vontade popular, propôs atribuí-lo à fortuna. Fez da eleição uma consulta aos deuses. Ao cabo de dous anos de luta, conseguiu Trumpbal a primeira vitória. - Pois bem, disseram-lhe; decretemos uma lei provisória, segundo o vosso plano; far-se-ão por ela duas eleições, e se não alcançar o efeito que esperais, buscaremos outra cousa. Assim se fez; a lei dura há quarenta e oito anos.

"Eis os lineamentos gerais do processo: cada candidato é obrigado a fazer-se inscrever vinte dias antes da eleição, pelo menos, sem limitação alguma de número. Nos dez dias anteriores à eleição, os candidatos expõem na praça pública os seus méritos e examinam os dos seus adversários, a quem podem acusar também, mas em termos comedidos. Ouvi um desses debates. Conquanto a língua ainda me fosse difícil de entender, pude alcançar, pelas palavras inglesas e latinas, pela compostura dos oradores e pela fria atenção dos ouvintes, que os oradores cumpriam escrupulosamente a lei. Notei até que, acabados os discursos, os adversários apertavam as mãos uns dos outros, não somente com polidez, mas com afabilidade. Não obstante, para evitar quaisquer personalidades, o candidato não é designado pelo próprio nome, mas pelo de um bicho, que ele mesmo escolhe no ato da inscrição. Um é águia, outro touro, outro pavão, outro cavalo, outro borboleta etc. Não escolhem nomes de animais imundos, traiçoeiros, grotescos e outros, como sapo, macaco, cobra, burro; mas a lei nada impõe a tal respeito. Nas referências que fazem uns aos outros adotaram o costume de anexar ao nome um qualificativo honrado: o brioso Cavalo, o magnífico Pavão, o indomável Touro, a galante Borboleta etc., fazendo dessas controvérsias, tão fáceis de azedar, uma verdadeira escola de educação. 
"A eleição é feita engenhosamente por uma máquina, um tanto parecida com a que tive ocasião de ver no Rio de Janeiro, para sortear bilhetes de loteria. Um magistrado preside a operação. Escrito o título do cargo em uma pedra negra, dá-se corda à máquina, esta gira e faz aparecer o nome do eleito, composto de grandes letras de bronze. Os nomes de todos, isto é, os nomes dos animais correspondentes têm sido postos na caixa interior da máquina, não pelo magistrado, mas pelos próprios candidatos. Logo que o nome de um aparecer, o dever do magistrado é proclamá-lo, mas não chega a ser ouvido, tão estrondosa é a aclamação do povo: - "Ganhou o Pavão! ganhou o Cavalo!". Este grito, repetido de rua em rua, chega aos últimos limites da cidade, como um incêndio, em poucos minutos. O alvoroço é enorme, é um delírio. Homens, mulheres, crianças, encontram-se e bradam: - "Ganhou o Cavalo! ganhou o Pavão!".

"Mas então os vencidos não gemem, não blasfemam, não rangem os dentes? Não, caro senhor, e aí está a prova da intuição política do reformador. Os cidadãos, levados pelo impulso que os faz não descrer jamais da fortuna, lançam apostas, grandes e pequenas, sobre os nomes dos candidatos. Tais apostas parece que deviam agravar a dor dos vencidos, uma vez que perdiam candidato e dinheiro; mas, em verdade, não perdem as duas cousas. Os cidadãos fizeram disto uma espécie de perde-ganha; cada partidário aposta no adversário, de modo que quem perde o candidato ganha o dinheiro, e quem perde o dinheiro ganha o candidato. Assim, em vez de deixar ódios e vinganças, cada eleição estreita mais os vínculos políticos do povo. Não sei se uma grande cidade poderia adotar tal sistema; é duvidoso. Mas para cidades pequenas não creio que haja nada melhor. Tem a doçura, sem a monotonia do víspora. E, deixai-me que vo-lo diga francamente, apelando para os seus deuses, este povo, que conserva as crenças errôneas da raça originária, pensa que são eles que o ajudam; mas, em verdade, é a providência divina. Ela é que governa a terra toda e dá luz à escuridão dos espíritos. Está em Isaías: "Ouvi, ilhas, e atendei, povos de longe". Está nos Salmos: "Do Senhor é a redondeza da terra e todos os seus habitadores, porque ele a fundou sobre os mares e sobre os rios". 
"Haveria muito que dizer se pudesse contar outros costumes deste povo, fundamentalmente bom e ingênuo; mas paro aqui. Conto estar de volta no Rio de Janeiro em fins de maio ou princípios de junho. Peço-vos que auxilieis o meu amigo rev. Maxwell; ele vai buscar-me alguns livros e um aparelho fotográfico. Indagai dele as suas impressões, e ouvireis a confirmação do que vos digo. Adeus, meu caro senhor; crede-me vosso muito obediente servo - GoING."

O rev. Maxwell confirma realmente tudo o que me diz a carta do rev. Going. São dous sacerdotes; e, embora protestantes, não creio que se liguem para rir de um homem de boa-fé. É tudo, porém, tão extraordinário que, para o caso de ser um simples humbug, resolvi publicar a carta. Os entendidos dirão se é possível a descoberta.

BENITO PETRAGLIA é doutor em Letras pela Universidade Federal Fluminense. Atualmente faz pós-doutorado na mesma instituição, com o projeto Machado de Assis e as crônicas de "A Semana". E-mail: benitop@id.uff.br. 